\title{
Fruit yield and quality of Palmer mango trees under different irrigation systems
}

\author{
Welson Lima Simões'*(D), Maria Aparecida do Carmo Mouco' ${ }^{(0)}$, Victor Pimenta Martins de Andrade ${ }^{2}$ (D), \\ Pedro Paulo Bezerra ${ }^{3}$ (D), Eugenio Ferreira Coelho 4 (D) \\ 'Embrapa Semiarid, Petrolina, Brazil \\ ${ }^{2}$ Federal Institute of Education, Science and Technology of Sertão Pernambucano, Santa Maria da Boa Vista, Brazil \\ ${ }^{3}$ Federal Rural University of Pernambuco, Recife, Brazil \\ ${ }^{4}$ Embrapa Cassava and Fruit, Cruz das Almas, Brazil \\ *Corresponding author, e-mail: welson.simoes@embrapa.br
}

\begin{abstract}
Mango production has been having a great economical expression in the Brazilian agriculture. However, the economic crisis and increased competitiveness of the international market required improvements in the crop efficiency for its sustainability. In this context, the objective of this work was to evaluate the effect of different irrigation system on the physiology and fruit yield and quality of Palmer mango trees in the semiarid conditions of the Lower Middle São Francisco Valley, Brazil. The experiment was carried out at the Agranvil Farm, in Petrolina, state of Pernambuco, Brazil, with harvests in July 2013 and October 2014. A randomized block statistical design was used, with four treatments replicated in 5 blocks, during two production cycles. The treatments consisted of four irrigation systems: one micro sprinkler under the plant canopy (MSPC); drip system with two lateral lines per plant row (DSLL); one micro sprinkler between plants (MSBP); and ring-shaped drip system around the plants (RSDS). All treatments provided a flow rate of $56 \mathrm{~L} \mathrm{~h}^{-1}$ plant $^{-1}$. The physiological characteristics evaluated were: photosynthesis, stomatal conductance, leaf transpiration, and leaf temperature. Fruit yield, quantity, mean weight, volume, soluble solid content, titratable acidity (TA), density, and pulp firmness were evaluated after the harvest. The evaluated treatments presented significant differences for the physiological variables. The treatment DSLL provided higher number of fruits and fruit yield, and the treatment MSBP provided the lowest results for these variables.
\end{abstract}

Keywords: Mangifera indica L., fruit yield, photosynthesis

\section{Introduction}

Production of mango (Mangifera indica L.) has been having a great economical expression in the Brazilian agriculture. The country produced approximately 1.1 million $\mathrm{Mg}$ of mangoes in the 2017 crop season, with average yield of $17 \mathrm{Mg}$ per hectare. The highest production is concentrated in the Northeast region, where the states of Bahia and Pernambuco have the greatest productions. The mango cultivar Palmer is planted in approximately $50 \%$ of the total mango area in the Lower Middle São Francisco Valley (Kist et al., 2019).

The rainfall depths in the Brazilian Semiarid region do not meet the crop water demand, which requires the use of irrigation (Soares et al., 2013). However, considering the good-quality water availability for irrigation and the intense solar radiation, high temperatures, and low air relative humidity in the Lower Middle São Francisco Valley, a proper crop management tends to result in a high fruit production and quality, and contributes to the success of this crop in the region (Leão et al., 2016).

According to Santos et al. (2019), mango crops cause no negative impacts on soil chemical attributes under semiarid conditions, only small changes in physical attributes due to practices commonly used for mango production. However, water resources have becoming scarcer each year, leading to the need of rational use of water and improvements in the efficiency of irrigation systems (Nascimento et al., 2017).

The productive and qualitative responses of plants to irrigation depend mainly on the frequency, time, method, and implementation of the irrigation system, crop stage, edaphoclimatic conditions, and cultivar used (Coelho et al., 2015). When using localized irrigation, the emitter distribution in the crop area can also affect the application efficiency and water distribution in the soil, even under the same irrigation time and water volume 
(Simões et al., 2017).

Despite several researches have been conducted on irrigated mango crops and Palmer is currently the most planted mango cultivar in the São Francisco Valley, the choice and arrangement of an irrigation system for this cultivar have not been defined, which should focus on interactions between plant, soil, and climate conditions of the region.

In this context, the objective of this work was to evaluate the effect of four irrigation systems on physiological variables and fruit yield and quality of Palmer mango trees in the semiarid conditions of the Lower Middle São Francisco Valley, Brazil.

\section{Material and Methods}

The experiment was conducted at the Agranvil Farm, in Petrolina, state of Pernambuco, Brazil $\left(09^{\circ} 24^{\prime} \mathrm{S}\right.$, $40^{\circ} 20^{\prime} \mathrm{W}$, and mean altitude of $370 \mathrm{~m}$ ), in a Typic Quartzipsamment, whose chemical attributes are shown in Table 1.

Table 1. Chemical attributes of the soil of the Palmer mango orchard.

\begin{tabular}{|c|c|c|c|c|c|c|c|c|c|c|c|c|}
\hline \multirow{2}{*}{ Layer (m) } & EC & \multirow[t]{2}{*}{$\mathrm{pH}$} & $P$ & K & $\mathrm{Na}$ & $\mathrm{Ca}$ & $\mathrm{Mg}$ & $\mathrm{Al}$ & $\mathrm{H}+\mathrm{Al}$ & SB & CEC & BS \\
\hline & $\mathrm{mS} \mathrm{cm}^{-1}$ & & $\mathrm{mg} \mathrm{dm}^{-3}$ & \multicolumn{8}{|c|}{$\mathrm{cmol}_{\mathrm{c}} \mathrm{dm}^{-3}$} & $\%$ \\
\hline $0-0.2$ & 0.24 & 6.5 & 0.95 & 0.16 & 0.03 & 1.4 & 1.1 & 0 & 0.2 & 2.7 & 2.9 & 94.4 \\
\hline $0.2-0.4$ & 0.15 & 5.7 & 27.86 & 0.19 & 0.03 & 0.7 & 0.3 & 0 & 0.8 & 1.2 & 2 & 60.4 \\
\hline
\end{tabular}

exchangeable potassium; $\mathrm{Al}$ = exchangeable acidity; $\mathrm{SB}=$ sum of bases; $\mathrm{CEC}=$ cation exchange capacity at $\mathrm{pH} 7.0 ; \mathrm{BS}$ = base saturation.

The climate of the region is BSh', dry and very hot, according to the Köppen-Geiger classification (Alvares et al., 2013), with mean relative air humidity of $61 \%$. Figure 1 shows the local climate data regarding reference evapotranspiration and mean temperature during the two crop cycles-September 2012 to October 2014.

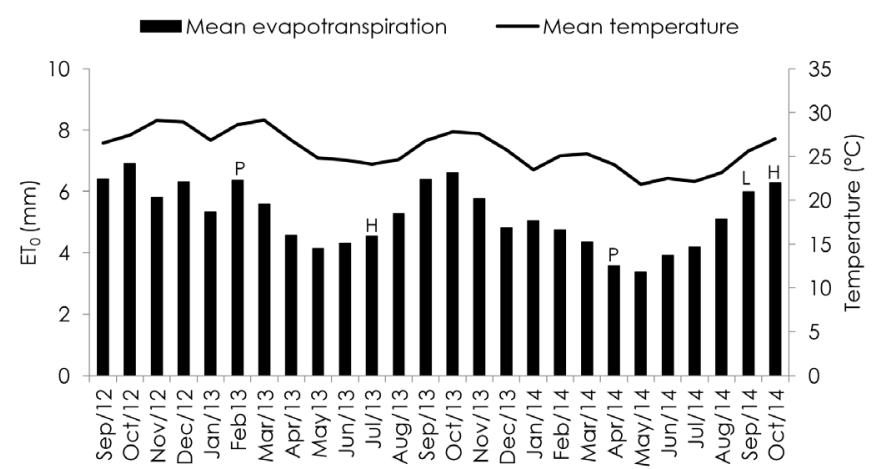

Figure 1. Monthly mean reference evapotranspiration (ETO) and temperature recorded by a meteorological station near the Agranvil Farm, in Petrolina, state of Pernambuco, Brazil. P: pruning, H: harvest, L: leaf physiological evaluation.

The orchard was composed of 9-year-old Palmer mango trees spaced $8 \times 5 \mathrm{~m}$ apart. Practices of soil fertilization, pesticide application, and floral induction were carried out according to Oliveira et al. (2015). The first cycle harvest was carried out on July 15, 2013, and the second cycle harvest on October 23, 2014.

A randomized block statistical design was used, with four treatments replicated in 5 blocks, during two production cycles. Each plot was composed of four plants, from which the two central plants were considered for evaluation. The treatments consisted of four irrigation systems: one micro sprinkler under the plant canopy, positioned at $0.3 \mathrm{~m}$ from the trunk (MSPC); drip system with two lateral lines per plant row (DSLL); one micro sprinkler between plants (MSBP); and ring-shaped drip system around the plants (RSDS), as commonly used by local producers. All treatments provided a flow rate of $56 \mathrm{~L} \mathrm{~h}^{-1}$ plant $^{-1}$. The treatments with drip irrigation had 14 drippers spaced $0.5 \mathrm{~m}$ apart, generating a wet range of $0.55 \mathrm{~m}$ width. The wet range (radius) in the treatments with micro sprinklers was $2.3 \mathrm{~m}$ (Figure 2).

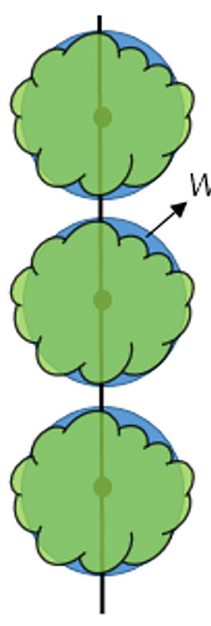

MSPC

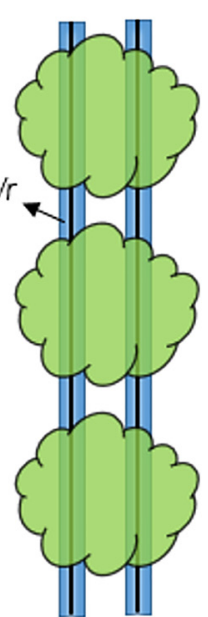

DSLL

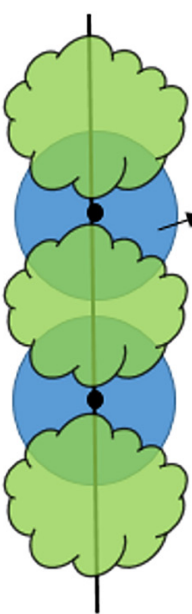

MSBP

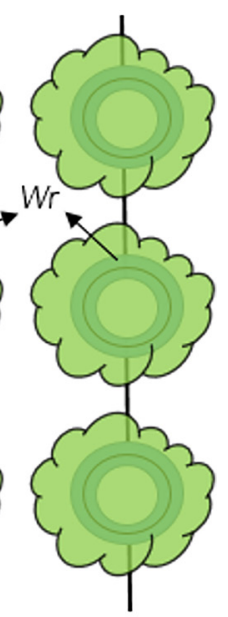

RSDS
$\mathrm{Wr}=$ wet range: $\mathrm{MSPC}=$ one micro sprinkler under the plant canopy; $\mathrm{DSLL}=$ drip system with two lateral lines per plant row; MSBP = one micro sprinkler between plants; and RSDS = and ring-shaped drip system around the plants.

Figure 2. Representation of the irrigation systems evaluated.

The plants were subjected to daily irrigations calculated by the Penman-Monteith method, using data from a meteorological station near the experiment site. The crop coefficients $(\mathrm{KC})$ used to determine crop evapotranspiration were the ones proposed by Teixeira et al. (2008) (Table 2).

Fruits were harvested from the mango trees in the evaluation area, and counted and measured to determine fruit yield, quantity, and mean weight. 
Table 2. Crop coefficients $(\mathrm{Kc})$ recommended for the different phenological stages of mango crops in Petrolina, PE, Brazil (Teixeira et al., 2008).

\begin{tabular}{cl}
\hline Phenological stage & Kc \\
\hline Rest & 0.7 \\
Vegetative growth & 0.8 \\
Branch maturation & 1.0 \\
Beginning of flowering & 1.0 \\
Fruit growth & 0.9 \\
Fruit maturation & 0.8 \\
Harvest & 0.6 \\
\hline
\end{tabular}

The fruit quality was evaluated in fruits harvested in each quadrant of plants (North, South, East, and West), according to their position in the canopy, constituting a split-plot arrangement. The fruits were stored in a cold chamber after harvest and, in the following day, they were analyzed for fruit quality in the Laboratory of PostHarvest Physiology of the Brazilian Agricultural Research Corporation (Embrapa Semiarid).

Fruit pulp firmness was determined using a manual penetrometer (FT 327; Effegi), and the measures were done after removing the peel, in two opposite points in the equatorial region of the fruits. Solid soluble content in the fruits was evaluated using a manual refractometer (Pocket pal-1). Titratable acidity was determined by titration of $1 \mathrm{~g}$ of fruit pulp homogenized and diluted in $50 \mathrm{~mL}$ distilled water with addition of three drops of the phenolphthalein indicator (1\% phenolphthalein); the titration was done using a digital burette under constant shaking, with a $\mathrm{NaOH} 0.1 \mathrm{~N}$ solution, and the results were expressed in grams of citric acid per $100 \mathrm{~g}$ of pulp (IAL, 2008).

Fruit yield and quality data were collected during the two cycles of the experiment and evaluated as splitplots. The physiology of the treated plants was evaluated through their photosynthesis (A), stomatal conductance (gs), leaf transpiration $(E)$, and leaf temperature $\left(T_{L}\right)$, using an Infrared Gas Analyzer device (Li 6400; Licor ${ }^{\circledR}$ ). The analyses were done in the crop fruiting stage, between 10:00h and 12:00h of a cloudless day, using physiologically mature leaves from the second third of branches containing fruits that were exposed to the Sun and free from mechanical damages, pests, and symptoms of diseases and nutritional deficiency.

The data were analyzed for normality by the Shapiro-Wilk test and subjected to analysis of variance; the means were compared by the Tukey's test at $5 \%$ probability.

\section{Results and Discussion}

The results of gas exchange in leaves of Palmer mango trees are presented in Table 3, which shows no significant differences for the different irrigation systems evaluated in the present work. The means found in the second productive cycle were $14.88 \mu \mathrm{mol} \mathrm{CO} \mathrm{CO}^{-2} \mathrm{~s}^{-1}$

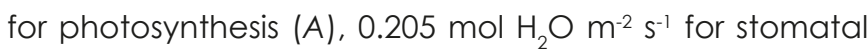
conductance (gs), $5.73 \mathrm{mmol} \mathrm{H}_{2} \mathrm{O} \mathrm{m} \mathrm{m}^{-2} \mathrm{~s}^{-1}$ for leaf transpiration $(E)$, and $33.06{ }^{\circ} \mathrm{C}$ for leaf temperature $\left(T_{L}\right)$. These indicators of gas exchanges were below those found by Simões et al. (2018) for fruits from Keitt mango trees grown in the Lower Middle São Francisco Valley and evaluated at the same phenological stage and same reading time, denoting the different hydrological demands of these cultivars.

Santos et al. (2016) reported that decreases in irrigation water depth of up to $50 \%$ of the ETc for Tommy Atkins mango at fruit maturation stage did not reduce leaf gas exchanges, denoting that it is a less sensitive

Table 3. Photosynthesis (A), stomatal conductance $(g s)$, leaf transpiration $(E)$, and leaf temperature $\left(T_{L}\right)$ in mango trees of the cultivar Palmer under different irrigation systems.

\begin{tabular}{|c|c|c|c|c|}
\hline Treatments & $A$ & gs & $E$ & $T_{L}$ \\
\hline & $\mu \mathrm{mol} \mathrm{CO} \mathrm{Cm}^{-2} \mathrm{~s}^{-1}$ & 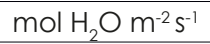 & $\mathrm{mmol} \mathrm{H}_{2} \mathrm{O} \mathrm{m}^{-2} \mathrm{~s}^{-1}$ & ${ }^{\circ} \mathrm{C}$ \\
\hline MSBP & $14.12^{\text {ns }}$ & $0.20^{\text {ns }}$ & $5.15^{\mathrm{ns}}$ & $32.97^{\mathrm{ns}}$ \\
\hline DSLL & $15.15^{\text {ns }}$ & $0.18^{\text {ns }}$ & $5.5^{\mathrm{ns}}$ & $33.2^{\text {ns }}$ \\
\hline MSPC & $16.98^{\text {ns }}$ & $0.20^{n s}$ & $6.45^{\text {ns }}$ & $32.99^{n s}$ \\
\hline RSDS & $13.29^{\text {ns }}$ & $0.24^{\mathrm{ns}}$ & $5.73^{\text {ns }}$ & $33.07^{\mathrm{ns}}$ \\
\hline
\end{tabular}

stage to water stress. This is consistent with the results from the physiological analyses of the present experiment, which presented no significant difference for the different irrigation systems tested.

The interaction between treatments and crop cycles was significant at $5 \%$ probability for fruit yield, number, and mean weight (Table 4), with no significant differences between fruits harvested in the different quadrants. The coefficients of variation for fruit yield, number, and mean weight were $6.55 \%, 6.38 \%$, and 14.30 between cycles, and $8.41 \%, 10.30 \%$, and $17.78 \%$ between irrigation systems, respectively. The treatments promoted no differences in fruit volume and density.

The highest fruit yields in all treatments were found in the second crop cycle. According to Sandip et al. (2015), a mild temperature is one of the main factors that stimulate flowering in mango trees. Thus, the higher temperatures in the first crop cycle than in the second 
Table 4. Yield, number and mean weight of Palmer mango fruits in two crop cycles under different irrigation systems.

\begin{tabular}{|c|c|c|c|c|c|c|}
\hline \multirow[t]{2}{*}{ Treatments } & \multicolumn{2}{|c|}{ Fruit number } & \multicolumn{2}{|c|}{ Fruit mean weight $(\mathrm{kg})$} & \multicolumn{2}{|c|}{ Fruit yield $\left(\mathrm{Mg} \mathrm{ha}^{-1}\right)$} \\
\hline & $\begin{array}{c}1^{\text {st }} \\
\text { cycle }\end{array}$ & $\begin{array}{c}2^{\text {nd }} \\
\text { cycle }\end{array}$ & $\begin{array}{c}1^{\text {st }} \\
\text { cycle }\end{array}$ & $\begin{array}{c}2^{\text {nd }} \\
\text { cycle }\end{array}$ & $\begin{array}{c}1^{\text {st }} \\
\text { cycle }\end{array}$ & $\begin{array}{c}2^{\text {nd }} \\
\text { cycle }\end{array}$ \\
\hline MSBP & $23.8 \mathrm{Bb}$ & $63.78 \mathrm{AC}$ & $0.57 \mathrm{Ab}$ & $0.43 \mathrm{Ba}$ & $13.75 \mathrm{BC}$ & $30.95 \mathrm{AC}$ \\
\hline DSLL & $48.9 \mathrm{Ba}$ & $94.20 \mathrm{Aa}$ & $0.53 \mathrm{Ab}$ & $0.42 \mathrm{Ba}$ & $31.02 \mathrm{Ba}$ & $39.70 \mathrm{Aa}$ \\
\hline MSPC & $47.3 \mathrm{Ba}$ & $77.88 \mathrm{Ab}$ & $0.64 \mathrm{Aab}$ & $0.41 \mathrm{Ba}$ & $30.55 \mathrm{Aa}$ & $32.55 \mathrm{Abc}$ \\
\hline RSDS & $32.0 \mathrm{Bb}$ & 76.04Ab & $0.79 \mathrm{Aa}$ & $0.43 \mathrm{Ba}$ & $25.38 \mathrm{Bb}$ & $35.31 \mathrm{Ab}$ \\
\hline
\end{tabular}

$\overline{M S B P}=$ one micro sprinkler between plants; $\mathrm{DSLL}=$ drip system with two lateral lines per plant row; $\mathrm{MSPC}=$ one micro sprinkler under the plant canopy and RSDS = and ring-shaped drip system around the plants. Means followed by uppercase letters comparing crop cycles for the same treatment, or lowercase letters comparing treatments for the same crop cycle, are not different by the Tukey's test at $5 \%$ probability.

crop cycle contributed to a lower flowering, resulting in lower number of fruits and, consequently, lower fruit yield. Another factor that may have contributed to this difference between the crop cycles was the alternance of production, which is a characteristic of mango crops, according to Oliveira et al. (2015).

According to Brecht et al. (2011), the international market demand varies according to the consumer's preference, which can be for fruits of 400 up to $900 \mathrm{~g}$; thus, the fruit mean weight found in both crop cycles is consistent with this standard.

In both crop cycles, the treatment with two lateral lines of drippers per plant row (DSLL) was the most efficient in terms of fruit yield, comparable only to the treatment with one micro sprinkler under the plant canopy (MSPC) in the first cycle. The DSLL treatment probably resulted in a better soil water distribution for the root systems, and maintained the soil wet longer. Considering machinery traffic on the interrows is essential for this system, since the interrows are not wetted may have compromised the activity of roots of treatments with micro sprinklers because of the soil densification. The plants presented greater sizes in the second cycle because of the homogenization of pruning in the first crop cycle; they formed a canopy with higher number of productive branches, which resulted in a higher soil water demand, which explains the fruit yield difference between the treatments DSLL and MSPC in the second crop cycle.
The treatment with one micro sprinkler between plants (MSBP) presented lower fruit yield than the other treatments, in both crop cycles. In this treatment, the emitter was positioned in a place with Sun exposition and low leaf density. Evaporation of water on the soil surface is dependent on the soil cover; the lower the shaded area, the higher the water evaporation, which can cause water deficiency for the crop (Simões et al., 2019). Thus, the bulbshaped wetted area of the treatment MSBP was formed under a little shaded area subjected to high evaporation rates, thus decreasing the soil water potential and water availability to plants. Similar results were found by Simões et al. (2018) for Keitt mango trees, and by Simões et al. (2017) for Tahiti lime trees; these studies found lower fruit yield when using micro sprinklers between plants when compared to other irrigation systems. Considering that mango fruits are approximately $82 \%$ water (Marques et al., 2010), soil water availability is essential for fruit growth.

The results of solid soluble contents (SS) and titratable acidity (TA) in fruits of each treatment are shown in Table 5. The interaction between crop cycles and treatments was significant for SS and TA, with no significant differences between the quadrants evaluated. The results found for fruit pulp firmness were similar between the treatments. The coefficients of variation found were $3.95 \%$ for SS and $6.66 \%$ for TA between crop cycles; and $12.19 \%$ for SS and $15.40 \%$ for TA between irrigation systems.

Table 5. Solid soluble contents (SS) and acidity titratable (TA) in Palmer mango fruits in two crop cycles under different irrigation systems.

\begin{tabular}{|c|c|c|c|c|}
\hline \multirow[t]{2}{*}{ Treatments } & \multicolumn{2}{|c|}{ SS ('brix) } & \multicolumn{2}{|c|}{ TA (\%) } \\
\hline & $1^{\text {st }}$ cycle & $2^{\text {nd }}$ cycle & $1^{\text {st }}$ cycle & $2^{\text {nd }}$ cycle \\
\hline MSBP & $7.94 \mathrm{Aa}$ & $6.44 \mathrm{Bb}$ & $1.42 \mathrm{Aa}$ & $0.85 \mathrm{Ba}$ \\
\hline DSLL & $8.15 \mathrm{Aa}$ & $7.14 \mathrm{Ba}$ & $1.00 \mathrm{Ac}$ & $0.78 \mathrm{Ba}$ \\
\hline MSPC & $8.34 \mathrm{Aa}$ & $6.70 \mathrm{Bb}$ & $1.24 \mathrm{Ab}$ & $0.62 \mathrm{Bb}$ \\
\hline RSDS & $8.42 \mathrm{Aa}$ & $6.48 \mathrm{Bb}$ & $1.08 \mathrm{AC}$ & $0.75 \mathrm{Ba}$ \\
\hline
\end{tabular}

MSBP = one micro sprinkler between plants; DSLL = drip system with two lateral lines per plant row; MSPC = one micro sprinkler under the plant canopy and RSDS = and ring-shaped drip system around the plants. Means followed by uppercase letters comparing crop cycles for the same treatment, or lowercase letters comparing treatments for the same crop cycle, are not different by the Tukey's test at $5 \%$ probability.

The results found for SS and TA were similar to those indicated by Brecht et al. (2011), who recommended that export mangoes should have SS between 7 and 9 Brix, and TA between 0.6 and $1.14 \%$. According to the authors, because it is a climacteric fruit, it has an increase in SS and a decrease in titratable acidity by approximately $3 \%$ per day under room temperature, which can be used to adequate the fruit quality to market demands.

The SS in the fruits at harvest were higher in the first crop cycle, in which there was no significant differences 
between the treatments. In the second crop cycle, the SS presented differences between treatments, with the treatment DSLL presenting the highest SS contents.

SS and TA were, in general, higher in the first crop cycle, which may be explained by the lower number of fruits produced, which caused a higher leaf area per fruit and less drains of synthetized photoassimilates, such as sugars and organic acids, as found for melon (Dalastra et al., 2014) and watermelon (Lins et al., 2016) fruits.

\section{Conclusions}

The irrigation with the drip system consisted of two lateral lines per plant row resulted in higher number of fruits, fruit yield, and solid soluble contents in fruits of Palmer mango trees grown in the Lower Middle São Francisco Valley, Brazil.

\section{References}

Alvares, C.A., Stape, J.L., Sentelhas, P.C., Moraes, G. de, Leonardo, J., Sparovek, G. 2013. Köppen's climate classification map for Brazil. Meteorologische Zeitschrift 22: 711-728.

Brecht, J.K., Sargent, A.S., Kader, A.A., Mitcham, E.J., Maul, F., Brecht, E.P., Menocal, O. 2011. Manual de práticas para melhor manejo pós-colheita da manga. National Mango Board, São Paulo, Brazil. 62 p.

Coelho, E.F., Silva, A.J.P., Donato, S.L.R., Santana Júnior, E.B., Oliveira, P.M. 2015. Sistemas de irrigação localizada e manejo de água em bananeira. Informe Agropecuário 36: 62-73.

Dalastra, G.M., Echer, M.M., Guimarães, V.F., Hachmann, T.L., Inagaki, A.M. 2014. Trocas gasosas e produtividade de três cultivares de meloeiro conduzidas com um e dois frutos por planta. Bragantia 73: 365-371.

Kist, B.B., Santos, C.E., Carvalho, C., Beling, R.R. 2019. Anuário Brasileiro de Horti \& Fruti. Gazeta Santa Cruz, Santa Cruz do Sul, Brazil. 96 p.

IAL - Instituto Adolfo Lutz. 2008. Métodos químicos e físicos para análise de alimentos. 4.ed. Normas analíticas do Instituto Adolfo Lutz, São Paulo, Brazil. 1020p.

Leão, É.L.S., Moutinho, L.M.G., Campos, L.H.R. 2016. Arranjo Produtivo Local da Fruticultura Irrigada do Vale do Submédio do São Francisco, Pernambuco/Bahia: Fluxos Comerciais e Dinamismo Local. Revista em Agronegócio e Meio Ambiente 9: 273-303.

Lins, H.A., Albuquerque, J.R.T. de, Queiroga, R.C.F. de, Silva Sá, F.V. da, Pereira, A. de M., Silva, A.B. da, Paiva, E.P de. 2016. Biomass accumulation, plant biometrics and fruit production of watermelon according to changes in source/drain relations. Comunicata Scientiae 7: 272-279.

Marques, A., Chicaybam, G., Araújo, M.T., Manhães, L.R.T., Sabaa-Srur, A.U.O. 2010. Composição centesimal e de minerais de casca e polpa de manga (Mangifera indica L.) cv. Tommy Atkins. Revista Brasileira de
Fruticultura 32: 1206-1210.

Nascimento, V.F., Feitosa, E.O., Soares, J.I. 2017. Uniformidade de distribuição de um sistema de irrigação por aspersão via pivô central. Journal of Neotropical Agriculture 4: 65-69.

Oliveira, M.B., Pereira, M.C.T., Mizobutsi, G.P., Mouco, M.A.C., Maia, V., Santos, E.F. 2015. Paclobutrazol and tip pruning in the management of 'Palmer' mango trees in the semi-arid region of Brazil. Acta Horticulturae 1075: $149-156$.

Sandip, M., Makwana, A., Barad, A., Nawade, B. 2015. Physiology of Flowering- The Case of Mango. International Journal Applied os Research 1: 1008-1012.

Santos, L., Lima, A., Rodrigues, M., Cunha, J., Santos, L., Soares, E., Silva, A., Souza, I. 2019. Does the irrigated mango cultivation in the semiarid change the Physical and chemical attributes of the soil. Comunicata Scientiae 10: $402-414$.

Santos, M.R.D., Donato, S.L.R., Coelho, E.F., Junior, C., Fernandes, P.R., Castro, I.N.D. 2016. Irrigation deficit strategies on physiological and productive parameters of 'Tommy atkins' mango. Revista Caatinga 29: 173-182.

Simões, W.L., Coelho, E.F., Martinez, M.A., Coelho Filho, M.A., Costas, E.L., Gomes, V.H.F. 2017. Produtividade e características físico-químicas dos frutos da lima ácida Tahiti sob diferentes disposições de microaspersores. Water Resources and Irrigation Management 6: 107-114.

Simões, W.L., Coelho Filho, M.A., Coelho, E.F., Guimarães, M.J.M., Santos, M.R., Costa, E.L. 2019. Transpiration, water extraction, and root distribution of Tahiti lime (Citrus latifolia Tanaka) plant under different micro-sprinkler placements. African Journal of Agricultural Research 14: 1369-1378.

Simões, W.L., Ferreira, P.P.B., Mouco, M.A.C., Guimarães, M., Silva, J.A.B. 2018. Produção e respostas fisiológicas da mangueira cv. Keitt sob diferentes sistemas de irrigação no Submédio do São Francisco. Irriga 23: 34-43.

Soares, C.A., Rocha Júnior, A.F., Silva, N.S., Mousinho, F.E.P., Zanini, J.R. 2013. Função de resposta do meloeiro a doses de adubação nitrogenada para dois níveis de irrigação. Comunicata Scientiae 4: 391-400.

Teixeira, A.H.C., Bastiaanssen, W.G.M., Moura, M.S.B., Soares, J.M., Ahmad, M.D., Bos, M.G. 2008. Energy and water balance measurements for water productivity analysis in irrigated mango trees, Northeast Brazil. Agricultural and Forest Meteorology 148: 1524-1537.

Conflict of Interest Statement: The authors declare that the research was conducted in the absence of any commercial or financial relationships that could be construed as a potential conflict of interest.

All the contents of this journal, except where otherwise noted, is licensed under a Creative Commons Attribution License attribuition-type BY. 